Journal of Finance and Accounting

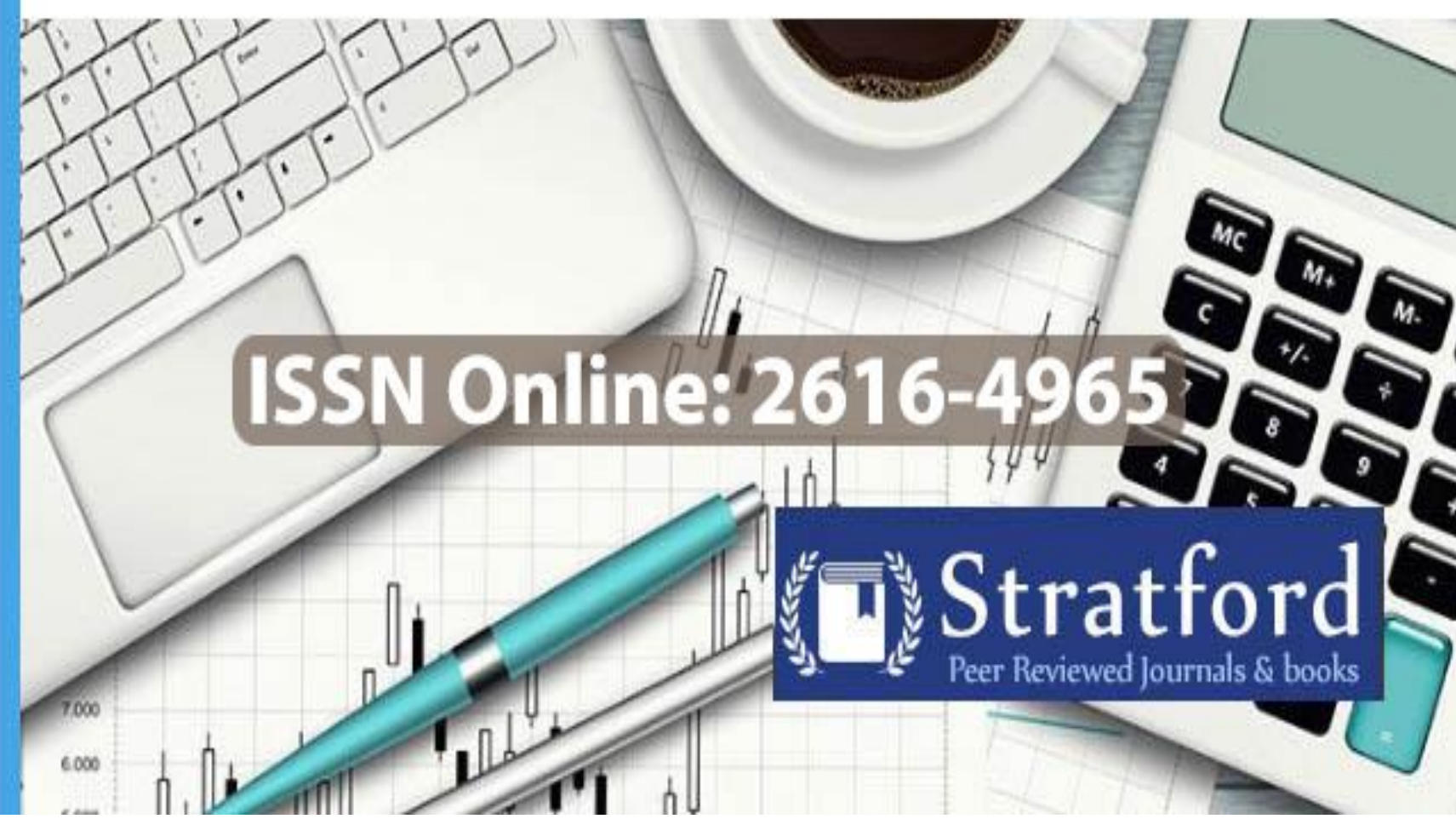

Effects of Loan Loss Provisions on Loans Disbursements Case Study of SACCOs in Kenya

Mutai Nelly Chelangat \& Joseph Kipkirui Mutai

ISSN: 2616-4965 


\title{
Effects of Loan Loss Provisions on Loans Disbursements Case Study of SACCOs in Kenya
}

\author{
${ }^{* 1}$ Mutai Nelly Chelangat \& Joseph Kipkirui Mutai ${ }^{2}$ \\ ${ }^{1,2}$ Department of Accounting and Finance \\ School of Business and Entrepreneurship, Bomet University College. \\ *Corresponding author's email address: neljerr@ymail.com
}

How to cite this article: Chelangat, M., N. \& Mutai, J., K. (2021). Effects of Loan Loss Provisions on Loans Disbursements Case Study of SACCOs in Kenya. Journal of Finance and Accounting, 5(4), 35-40. https://doi.org/10.53819/81018102t3018

\begin{abstract}
The study sought to establish the relationship between interest rates and loan provision in SACCOs in Kenya. Descriptive survey research design and stratified random sampling method were used. The sample size used was 84 respondents comprising of three operation managers, four credit officers, three customer service officers and seventy-four registered Sacco's members. The study was guided by Classical interest, Keynesian Liquidity and Time preference theories. Results indicated that interest rates charged on loans had the least influence on loan provisions. The study recommends that the government through Central Bank and Kenya Bankers Association to advocate for more market-based regulations which would ensure affordable and accessible financing for the small businesses and startups that promotes enabling environments for entrepreneurial activities. The findings contributed to new knowledge to literature and theory.
\end{abstract}

Keywords: Loan, Loss Provision, Loan Disbursement, Farmers, SACCO. 


\section{Introduction.}

Kenya's financial sector is dominated by commercial banks, insurance companies and pension schemes who have roots to the colonial period and were historically oriented towards meeting the financial needs of external trade and large scale commerce. These financial institutions do not therefore have a track record of lending to households and start-up small enterprises. When the Kenya Government recognized this shortfall, it embarked on initiatives such as savings and credit cooperatives (Sacco's), Small Enterprises Finance Company (SEFCO), Kenya Industrial Estates (KIE) and other alternatives to fill the financing gap that was there then according to Kimuyu (1998).

This brought about the SACCO industry in Kenya, the largest in Africa with over 3.5 million members and a $\$ 2$ billion loan portfolio. Within the micro finance (MFI) sector, another potential 4 million clients exist with a $\$ 300$ 0million portfolio, Kimuyu (1998). Their participation goes beyond simple Information exchange. Anecdotal evidence points to potential consumers who have multiple borrowings within SACCOs/MFIs and between in addition to the same consumer obtaining finance from the formal banking sector (FSD Kenya) 2012.

SACCOs are in the business of safeguarding money and other valuables for their members besides providing loans and offering investment financial services. Credit creation is the main income generating activity for the SACCOs, but this activity involves huge risks to both the lender and borrower. The risk of a member not fulfilling his or her obligation as per the contract on due date or anytime thereafter can greatly jeopardize the smooth functioning of a SACCO's business, Kimuyu (1998).

Loans are the largest source of credit risk to a financial institution. The goal of credit risk management is to maximize a SACCOs risk adjusted rate of return by maintaining credit risk exposure within acceptable parameters. SACCOs need to manage credit risk inherent to the entire portfolio as well as the risk in individual credits as transaction (Sinkey.1992). The success of credit management is mainly determined by the level of risk management in place, policies and procedures, professionalism and governance. Minimizing bad loans has benefits to all parties involved especially the lenders.

Gisemba (2010) researched on the relationship between risk management practices and financial performance of Sacco's found out that the Saccos adopted various approaches in screening and analysing risk before awarding credit to client to minimize loan loss. This includes establishing capacity, conditions, use of collateral, borrower screening and use of risk analysis in attempt to reduce and manage credit risks. He concluded that for Saccos to manage credit risks effectively they must minimize loan defaulters, cash loss and ensure the organization performs better increasing the return on assets.

\section{Statement of the problem}

According to WOCCU (2008), increasing profitability is a priority for all managers in financial institutions. For SACCO managers, collateral requirement policies are equally very important. On one hand SACCO managers need to reduce the risk of loan default because the institutions financial viability is weakened by the loss of principal and interest, yet on the other hand

\section{https://doi.org/10.53819/81018102t3018}


SACCO's operate under objectives of maximizing benefits to members which include the social role of providing loans to help members achieve their standard of living goals. These social roles conflict with financial viability of SACCO's' if managers become less stringent in the collateral requirement lending practice to assess and monitor the credit risk of member borrowers. This calls for the need to conduct more research on collateral requirement policies in SACCOs.

Despite the creation of a Risk Management Department at Kipsigis farmers Sacco, which is responsible for managing the SACCO's risks including credit risk, available records show a rise in the value of non-performing loans of the Sacco. In relation to lending activities, the Kipsigis Farmers Sacco's ratio of non-performing loans to total loans rose to 19 percent in 2017 from just 2.0 percent in 2016 (Kipsigis Farmers Sacco financial report, 2017).

This is a very disturbing phenomenon because if the high level of non-performing assets in the SACCO's portfolio is not brought under control, it may erode the capital base of the SACCO and reduce its profitability. The worst case can happen where liquidation or bankruptcy may occur due to the SACCO's inability to manage its credit risk efficiently. Is there a lax in implementation of credit risk policies i.e. Collateral requirement policies? This study attempts to answer these questions by evaluating the existing collateral requirement policies of the SACCO in order to identify the strengths and weaknesses and most importantly exploring ways of improving upon them. They also attempt to close this gap by providing further insights and information on the effect of collateral requirement practices on lending portfolios of SACCOs', (Kipsigis Framers SACCO financial report, 2009).

\section{Literature Review}

Gisemba (2010) researched on the relationship between risk management practices and financial performance of Sacco's found out that the Saccos adopted various approaches in screening and analysing risk before awarding credit to client to minimize loan loss. This includes establishing capacity, conditions, use of collateral, borrower screening and use of risk analysis in attempt to reduce and manage credit risks. Gisemba (2010) concluded that for Saccos to manage credit risks effectively they must minimize loan defaulters, cash loss and ensure the organization performs better increasing the return on assets.

Owusu (2008) on credit practices in rural banks in Ghana found out that the appraisal of credit applications did not adequately assess the inherent credit risk to guide the taking of appropriate credit decision he also found out that the drafted credit policy documents of the two banks lacked basic credit management essentials like credit delivery process, credit portfolio mix, basis of pricing, management of problem loans among others to adequately make them robust. In his recommendations Owusu (2008) stated that credit amount should be carefully assessed for identified projects in order to ensure adequate funding. This situation provides the required financial resources to nurture projects to fruition, thus forestalling diversion of funds to other purposes, which may not be economically viable.

\section{Methodology}

This study focused on cross-sectional descriptive survey design. Stratified random sampling was applied in carrying out the study as per the category of the respondent, a sample of $30 \%$ of the total population was used therefore 25 respondents constituted the sample population. The study

https://doi.org/10.53819/81018102t3018 
used primary data collected by use of structured questionnaires from 25 registered farmers and Likert type scale as the rating scale in questionnaires.Data collected was mostly qualitative in nature and was analyzed by descriptive analysis techniques. Quantitative data collected was analyzed using SPSS and was presented through percentages, means, standard deviations and frequencies.Results of the analysis were presented using tables.

\section{Results.}

Results showed that majority of respondents $(76 \%)$ were females while minorities (24\%) were males. Results also showed $68 \%$ of the respondents which is the biggest percentage were single while $24 \%$ and $8 \%$ of the respondents married and divorced respectively. Results also revealed that $48 \%$ of the respondents were in the $26-35$ age groups which were the majority. $24 \%$ were under 25 years, $16 \%$ between 36 and 45 years while $12 \%$ which is the minority is above 46 years. Further, results showed Kipsigis Farmers Sacco clients are fairly educated able to have capacity to understand questionnaires and answer accordingly. $72 \%$ of the respondents were found to be at the degree level, $20 \%$ were at diploma level while the minorities $(8 \%)$ were found to be at the primary level.

Table 1: Consideration of collateral

\begin{tabular}{|l|l|l|l|l|l|}
\hline & $\mathrm{N}$ & Minimum & Maximum & Mean & Std. Deviation \\
\hline $\begin{array}{l}\text { Kipsigis Farmers Sacco takes into } \\
\text { consideration historical record before } \\
\text { asking for collateral. }\end{array}$ & 25 & 1 & 4 & 1.64 & 1.114 \\
\hline $\begin{array}{l}\text { Customer trustworthiness is considered } \\
\text { first before collateral requirement }\end{array}$ & 25 & 2 & 5 & 3.12 & 1.092 \\
\hline $\begin{array}{l}\text { Loan amount applied for determines } \\
\text { whether there is need for collateral. }\end{array}$ & 25 & 1 & 4 & 2.16 & .898 \\
\hline $\begin{array}{l}\text { Need for a guarantor substitutes the need } \\
\text { for collateral. }\end{array}$ & 25 & 1 & 5 & 2.28 & 1.400 \\
\hline Valid N(Listwise) & 25 & & & & \\
\hline
\end{tabular}

The study also sought to investigate the factors that are considered by the SACCO before issuing loans to their clients. On a scale of 1 to 5 where 1 represented strongly disagree and 5 strongly agree, the findings reveal that only one of the factors is considered least when assessing collateral requirement. This factor is historical record of borrowing of the client, had a mean of 1.64. It was further established that two other factors: loan amount and need of a guarantor had means of 2.16 and 2.28 respectively, are considered moderately. Customer trustworthiness was considered crucial, had a mean of 3.12 . 
Table 2: Assessment on effect of collateral Requirement on Loan Provision.

\begin{tabular}{|l|l|l|l|l|l|}
\hline & N & Maximum & Minimum & Mean & Std. Deviation \\
\hline $\begin{array}{l}\text { Collaterals requirements } \\
\text { negatively affect loan provisions } \\
\text { in Kipsigis Farmers Sacco }\end{array}$ & $\mathbf{2 5}$ & $\mathbf{1}$ & $\mathbf{5}$ & $\mathbf{2 . 4 4}$ & $\mathbf{1 . 8 2 8}$ \\
\hline Valid N (Listwise) & $\mathbf{2 5}$ & & & & \\
\hline
\end{tabular}

On a scale of 1 to 5 where 1 represented strongly disagree and 5 strongly agree, it was found out that collaterals was crucial in determination of loan provisions with means of 2.44. While interest

Table 3: Model coefficient.

\begin{tabular}{|l|l|l|l|l|l|}
\hline Model coefficients & \multicolumn{2}{|l|}{$\begin{array}{l}\text { Unstandardized } \\
\text { Coefficients }\end{array}$} & $\begin{array}{l}\text { Standardized } \\
\text { Coefficients }\end{array}$ & $\mathbf{t}$ & Sig. \\
\hline \multirow{2}{*}{ (Constant) } & B & St. Error & Beta & & \\
\cline { 2 - 6 } Collaterals. & 154.24 & 3137.67 & .523 & 2.653 & .000 \\
& -.896 & .201 & -.086 & -.952 & .544 \\
\hline
\end{tabular}

The table of coefficients above reveals that collaterals has a positive coefficient of 24.387 The findings further indicate that if the independent variables assume a value of zero, then the loan provision constant will be 154.24.

\section{Conclusion}

It was certain from the study findings that the Collateral requirements play a very significant role in rating the soundness of the Sacco's credit policy bearing a coefficient of (24.387). The study further established that the main significance of risk identification in Kipsigis Farmers Sacco is to ensure that risk management is practiced in the organization. The goal of credit risk management is to maximize the Sacco risk adjusted rate of return by maintaining credit risk exposure within acceptable parameters.

Most SACCOs in Kenya have a loan risk management policy in place. This policy is very crucial in providing guidelines on how to manage the various risks these organizations encounter in their lending activities. Minimizing bad loans has benefits to all parties involved especially the lenders First and foremost it will help in the identification of potential credit risks related to loan restructuring, underwriting and documentation. Secondly, it will assist in selecting appropriate solutions to solve emerging credit problems by using strategies that optimizes the outcome for the institution. 


\subsection{Recommendations}

The study has revealed that collaterals is of high importance in loan provision. Therefore, Kipsigis Farmers Sacco should ensure that there are policies on collateral requirements put in place in order to improve their loan portfolios.

It will also be important if the SACCOs can also consider using collateral policy documents from other successful similar organizations as a benchmark for best practices.

\section{REFERENCE}

Asiedu-Mante, E. (2002). "Silver Jubilee Celebration of the Rural Banking in Ghana", The Rural Banker, January - June, 2002

Basel Committee on Banking Supervision, "Principles for the Management of Credit Risk",September 2000.

Basel. (1999). Principles for the Management of Credit Risk. Basel Committee on Banking Supervision, Basel

Chijoriga, M. M. (1997). Application of Credit Scoring and Financial Distress Prediction Models to Commercial Banks Lending: The Case of Tanzania. Ph.D. Dissertation, Wirts Chaftsnnversitat Wien (WU), Vienna.

Christen R. and D.Pearse, (2005) Managing Risks and Designing Products for Agricultural Microfinance: Features of an Emerging Model. Occasional Paper NO: 11Consultative Group to assist the Poor. Vol 8.

Eldelshain, D. (2005) "British Corporate Currency exposure and Foreign Exchange risk Management” London Business School. London Ph.D. Thesis

Gaitho.M (2010).Credit risk management practices by Saccos in Nairobi. Unpublished MBA project.

Gasbarro, D., Sadguna I. M., \& Zumwalt J. K. (2002). The Changing Relationship between CAMEL Ratings and Bank Soundness during the Indonesian Banking

Gisemba, P. N. (2010). The Relationship between Credit Risk Management Practices and Financial Performance of SACCOs in Kenya. Unpublished MBA Dissertation, University of Nairobi.

Jansson.T. (2002), Performance Indicators for MFI's: Technical Guide. Micro Rate and InterAmerican Development Bank, Washington, DC available at www.microrate.com

Kimuyu, P. (1998). Industrial Policies for the Twenty First Century: Productivity, Competitiveness and Export Participation by Manufacturing Enterprises in Kenya, paper presented at IPAR National Conference, Nairobi.

Long staff, P., Schwartz, E. (1995) "A simple approach to valuing risky fixed and floating rate debt "Journal of Finance, 5 (1), 789-819. Michael, Sproul. (1998). The Quantity Theory Versus the Real Bills Doctrine in Colonial America. In Economics Working Papers.

Markowitz H.M (1952), Portfolio Selection. Journal of Finance, Vol 7 no1. https://doi.org/10.2307/2975974. 